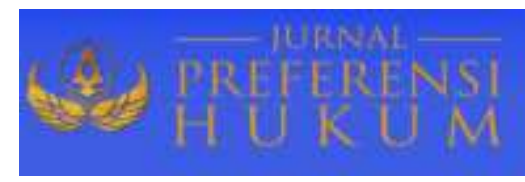

Jurnal Preferensi Hukum | ISSN: 2746-5039

Vol. 2, No. 2 - Juli 2021, Hal. 271-275| Available online at

https://www.ejournal.warmadewa.ac.id/index.php/juprehum

DOI: https://doi.org/10.22225/jph.2.2.3321.271-275

\title{
TINJAUAN HUKUM HAK BELI KEMBALI DALAM PERJANJIAN JUAL BELI SAHAM DI PASAR MODAL
}

\author{
Putra Umbu Sangera, I Nyoman Putu Budiartha Ni Gusti Ketut Sri Astiti \\ putraumbusangera3630@gmail.com, budiarthapuru59@gmail.com, notarisppatsriastiti@yahoo.com \\ Fakultas Hukum, Universitas Warmadewa, Denpasar-Bali, Indonesia
}

\begin{abstract}
Abstrak
Perjanjian hak beli kembali yaitu bentuk kesepakatan yang terjadi dan di temui di kehidupan masyarakat, seperti halnya pedagang yang dapat mengambil kembali barangnya yang sudah dijual dengan ketentuan-ketentuan tertentu seperti yang tertuang dalam pasal 1519 KUHPerdata. Tujuan penelitian ini untuk mengungkap tinjauan hukum hak membeli kembali dalam perjanjian jual beli saham di pasar modal. Tipe kajian yang dipakai dalam meneliti adalah penelitian hukum normatif dengan pendekatan perundang-undangan (statute approach). Sumber bahan hukum dalam penelitian ini adalah bahan bukum primer seperti teori hukum positif normatif yang berdiri di atas doktrin bahwa hukum identik dengan norma murni dalam arti obyektif bebas dari nilai ideologis, etis, sosiologis. Teknik pengumpulan bahan hukum yang digunakan adalah dengan cara membaca dan mengutip dengan menganalisa perundang-undangan yang berlaku dan menggunakan catatan kecil yang diambil dari buku, literatur, dan sumber lainnya yang berkaitan dengan permasalahan yang dibahas. Data yang telah diperoleh kemudian di dianalisis dan disajikan secara kualitatif. Hasil penelitian menunjukkan bahwa hak dan kewajiban para pihak jual beli saham di pasar modal harus setara dan adil, sebelum hak dan kewajiban setara, adil, dan dilaksanakan pasti terlebih dahulu melakukan kesepakatan. Upaya hukum yang dapat diambil jika terjadi pelanggaran kontrak dapat dilakukan melalui pengadilan eksternal (non litigasi) dan pengadilan (litigasi).
\end{abstract}

Kata Kunci: Hak Membeli Kembali, Pasar Modal, Penegak Hukum.

\begin{abstract}
A repurchase right agreement is a form of agreement that occurs and is found in people lives, such as residents who can take back their goods that have been sold under certain provisions as set out in article 1519 of the Civil Code. The aim of this research was to determine the legal review of the right to buy back in the share sale and purchase agreement in the capital market. The type of research used is normative with statutory approach. The source of legal material in this research is primary such as positive normative legal theory which stands on the doctrine that law is identical to pure norms in an objective sense free from ideological, ethical, and sociological values. The technique of legal materials used is by reading and quoting by analyzing willing invitations and using small notes taken from books, literature, and other sources related to the issues discussed. The data that has been obtained are then analyzed and analyzed qualitatively. The result shows that the rights and obligations of the parties who sell shares in the capital market must be equal and fair, before the rights and obligations are equal, fair, and implemented, they must first make an agreement. Legal remedies that can be taken if a contract error occurs can be made through external courts (non-litigation) and courts (litigation).
\end{abstract}

Keywords: Repurchase Agreement, Capital Market, Law Enforcement.

\section{PENDAHULUAN}

Ketahanan ekonomi bisa diukur dengan berbagai macam cara, yairu dengan cara melihat ketersedian sumber daya alam maupun sumber daya manusia, kelembagaan ekonomi, kapasitas produksi, dan produksi tinggi atau investasi (Dougall, 2004). Penanaman modal dalam hal ini dapat dibedakan menjadi 3 (tiga) bagian yaitu penanaman modal finansial, penanaman modal komoditas dan penanaman modal sektor riil (Sawidji, n.d.). Penanaman modal komoditas adalah penanaman modal hal yang dilaksanakan melalui barang komoditas yang digantikan dengan komoditas lain dengan tipe yang sama atau disebut juga dengan perdagangan berjangka. Penanaman modal riil atau sering disebut juga investasi langsung yang dilakukan dengan cara mendirikan perusahaan pada sektor usaha tertentu, pembukaan lahan perkebunan, pertambangan dan sebagainya. lnvestasi keuangan dibedakan menjadi dua bagian yaitu investasi pasar uang dan investasi pasar modal. 
Berbagai fakta membuktikan bahwa perusahaan-perusahaan yang dianggap kuat dan tidak mampu menahan guncangan ekonorni harus menyerah dalam menghadapi krisis. Guncangan ekonorni di Amerika Serikat dan perekonomian di Eropa berdampak cukup besar bagi dunia, terrnasuk Indonesia. Maka daripada itu kegentingan yang dialami di AS dan Eropa berdampak kecil bagi lndonesia, meskipun telah banyak menimbulkan dampak yang merugikan bagi perekonomian dunia dan pasar modal.

Pertumbuhan ekonomi dunia telah membawa perubahan besar di semua lini kehidupan, diantaranya adalah menanamkan modal aset kekayaan maupun dananya yang berupa uang melalui pasar modal. Hampir setiap negara, investasi merupakan topik pembicaraan. Dilihat dari segi kematangan pasar modal adalah parameter pembangunan ekonomi di dalam sebuah negara, termasuk perputaran perekonomian suatu negara yang merupakan sumber dana bagi penyelenggaraan tulang punggung perekonomian suatu negara.

Pembelian kembali saham termasuk istilah corporate litigation yang mengacu pada tindakan perusahaan tercatat akan mengambil kembali saham yang sudah diberikan maupun sudah dimiliki oleh pemegang saham. Pada dasarnya konsep repurchase yang digunakan di Indonesia adalah perusahaan dapat mengontrol saham yang dibeli kembali untuk jangka waktu tertentu, kemudian dapat membeli kembali untuk jangka waktu tertentu, kemudian dapat dibeli kembali saham tersebut dengan cara mengurangi modal. Saham yang dihasilkan dari pembelian kembali tidak akan langsung dibatalkan untuk memangkas modal sebagai yurisdiksi di suatu daerah lainnya. Implementasi rencana beli kembali saham tidak bisa dilaksanakan oleh PT atau perusahaan. Pembelian kembali saham merupakan tujuan dari aturan keterbukaan, dan pembelian kembali dilaksanakan berlandaskan metode penjualan efek yang sudah disepakati sebelumnya. Maka karena itu ada kelompok lain yang bergabung dalam membantu dilaksanakan pembelian kembali saham tersebut.

Kegiatan membeli kembali saham tersebut memasuki pasar modal Indonesia per tahun 2008. Sejumlah PT berharap dapat mengambil lagi sahamnya sebab biaya sahamnya sedang berada di posisi terbawah. keadaan pasar yang melandai memang pemberi harapan bagi PT atau perusahaan publik dalam upaya mengambil lagi sahamnya. Berdasarkan situasi tersebut diatas maka mendorong Perseroan Terbatas atau perusahaan publik guna menaikkan nilai persahamnya untuk memperoleh keuntungan jika melakukan pemasaran ulang.

Berawal dari banyaknya kepentingan perseroan terbatas atau perusahaan publik yang membeli kembali, dan sesuai dengan ketentuan yang bertentangan, perlu dikaji cara perlindungan hukum unruk melindungi hak pemegang saham minoritas dan pemegang saham mayoritas guna menjaga kepercayaan investor terhadap pemodal. Mempertahankan kelembagaan pasar modal agar dapat dibandingkan dengan peraturan yang sama di negara lain akan memberikan ruang lingkup yang mendukung perkembangan pasar modal di Indonesia. Oleh karena itu, kebijakan yang diterapkan pemegang saham mayoritas atau investor dan segenap aktivitas yang dilaksanakan oleh aparatur penegak keadilan maka akan berada dalam situasi atau kondisi hukum yang sesuai, maka hal tersebut tidak bertolak belakang serta diharapkan bersinergi dengan baik.

Kedudukan perjanjian jual beli saham dengan hak membeli kembali yang berlaku di Indonesia telah diatur di dalam peraturan perundang-undangan yakni di dalam Pasal 1532, Pasal 1519 KUHPerdata, Undang-Undang tentang Pasar Modal, Ketentuan Peraturan yang dikeluarkan oleh Otoritas Jasa Keuangan dan Lembaga terkait lainnya (Sandrawati et al., 2018). Suatu perjanjian jual beli dengan hak membeli kembali menjadi sah selama tidak menjual barang atau saham kepada orang lain sesuai ketentuan jangka waktu yang ditetapkan, sebab suatu saat barang atau saham tersebut akan diserahkan kembali. Akan tetapi kalaupun barang itu dijual kepada orang lain maka si penjual tetap berhak membeli kembali barang tersebut dari pembeli kedua (Tumewu, 2018). Dalam hal ini, melaksanakan pembelian kembali saham mengindikasikan kegiatan merupakan salah satu kebijakan yang perlu diperhatikan oleh perusahaan yang ingin meningkatkan harga saham serta ingin memperoleh keuntungan yang lainnya (Mufidah, 2013).

Maka berdasarkan penjelasan diatas, tujuan dari penelitian ini untuk mengungkap tinjauan hukum hak membeli kembali dalam perjanjian jual beli saham di pasar modal. 


\section{METODE PENELITIAN}

Bentuk pengkajian yang diaplikasikan untuk mengungkap permasalahan dalam penelitian ini adalah penelitian hukum normatif yang prosedurnya untuk menemukan kebenaran dari aspek normatif menurut logika ilmiah hukum dengan pendekatan perundang-undangan (statute approach), pasal-pasal serta pandangan para ahli yang ada kaitannya dengan pelaksanaan perjanjian beli kembali (buyback). Sumber bahan hukum merupakan tempat memperoleh bahan hukum dalam penelitian ini seperti teori hukum positif normatif yang berdiri di atas doktrin bahwa hukum identik dengan norma murni dalam arti obyektif bebas dari nilai ideologis, etis, sosiologis (Atmaja \& Budiartha, 2018). Sumber bahan hukum dalam penelitian ini adalah bahan bukum primer seperti teori hukum positif normatif yang berdiri di atas doktrin bahwa hukum identik dengan norma murni dalam arti obyektif bebas dari nilai ideologis, etis, sosiologis. Teknik pengumpulan bahan hukum yang digunakan adalah dengan cara membaca dan mengutip dengan menganalisa perundang-undangan yang berlaku dan menggunakan catatan kecil yang diambil dari buku, literatur, dan sumber lainnya yang berkaitan dengan permasalahan yang dibahas. Data yang telah diperoleh kemudian di dianalisis dan disajikan secara kualitatif.

\section{HASIL DAN PEMBAHASAN}

1. Tinjauan Hukum Hak Membeli Kembali Dalam Perjanjian Jual Beli Saham di Pasar Modal. Istilah saham sering muncul didalam UU No. 40 tentang Perseroan Terbatas tahun 2007 dan UU No. 8 tentang pasar modal tahun 1995. Ada 3 pihak lain yang dapat ditemukan di bursa efek, yakni

1) Pemangku emisi daJam pasar modal yang mempunyai tupoksi besar, dikarenakan mempunyai tugas jika wanprestasi dalam melaksanakan oleh emiten di bursa efek, maka melihat underwider yaitu bank komersial, investasi bank, atau pun pialang.

2) Betul masing-rnasing kegiatan jual ataupun beli sekuritas di bursa efek, seorang broker atau pialang akan menemukan keberadaan pialang. Tupoksi utama broker adalah bertindak untuk menjadi penengah perdagangan, menghubungkan pemodal dan emiten.

3) Administrator investasi yaitu yang mempunyai kewenangan seperti nasabah yang sudah ditunjuk oleh investasi.

Selama ini pengaturan di Indonesia belum melakukan pengawasan terhadap saham, namun menurut UU Nomor 40 Tahun 2007 (UU Perseroan Terbatas), dapat diketahui bahwa saham merupakan salah satu unsur modal hukum suatu perusahaan. Menurut pasal 7 ayat (2) UUPT disebutkan bahwa setiap pendiri perseroan wajib memiliki sebagian saham pada saat perseroan didirikan. Dengan demikian dapat dikatakan sebagai bukti adanya kepemilikan saham.

Untuk mengangkat direksi dan komisaris perseroan terbatas, seseorang harus memenuhi persyaratan RUPS, namun tentunya harus memenuhi persyaratan yang ditentukan oleh peraturan perundang-undangan yang berlaku di Indonesia, sekalipun pernegang sahamnya mampu bertindak sebagai perseroan lembaga RUPS adalah lembaga untuk perusahaan dengan kekuasaan lebih dari direksi dan dewan komisaris, peraturan dan persyaratan tertentu masih harus dipenuhi, termasuk pembatasan kepemilikan saham dan kebutuhan untuk rnenjadi pemegang saham unruk memenuhi.

Pasal 48 ayat 2 anggaran dasar perseroan dapat rnengatur ketentuan tentang kepemilikan saham, dan harus memenuhi ketentuan otoritas yang berwenang yang diatur oleh peraturan perundang-undangan (Darmadi, 2016). Instansi yang berwenang rnengacu pada kewenangan untuk rnengawasi perusahaan sesuai dengan Undang-undang dalam Peraturan Presiden (Perpres) No. 44 tahun 2016 yang meliputi daftar wilayah usaha tertutup dan daftar wilayah usaha terbuka yang diwajibkan di departemen penanaman modal Perpres tersebut secara garis besar membagi wilayah usaha menjadi tiga kategori, yaitu kawasan usaha tertutup, kawasan usaha bersyarat, kawasan usaha pencadangan atau kemitraan dengan usaha mikro, kecil, menengah dan koperasi, serta kawasan usaha dengan syarat tertentu.

Kedudukan hukum saham minoritas terhadap pelaksanaan hak beli kembali saham (Widjaja, 2009). Hak Dasar yang dimiliki perusahaan adalah

1) Hak untuk ikut serta dalam pengurusan perseroan, serta pemilihan anggota direksi dengan hak suara proporsional dengan kepemilikan sahamnya di perseroan, dan untuk menentukan kebijakan strategis perseroan.

2) Hak menerima keuntungan dalam bentuk deviden yang dibagikan oleh perusahaan. 
3) Hak untuk memperoleh bagian dari kekayaan bersih dari perusahaan. Jika perusahaan atau dilikuidasi, termasuk hak untuk membagikan dividen dan hak untuk membayar kembali.

4) Hak untuk merubah kontrak pembentukan perusahaan, AD/ART perusahaan.

Termasuk asas untuk menyetujui perubahan pada kontrak pembentukan perusahaan, AD perusahaan dan asas untuk mempertahankan perbandingan kepemilikan saharn di perusahaan. Asas untuk melindungi jumlah relatif saham yang dikuasai oleh perusahaan dengan membeli saham baru yang dikeluarkan oleh perusahaan disebut prioritas. Jika perusahaan menerbitkan atau menerbitkan saham baru pemegang saham dapat membeli banyak saham. Oleh karena iru, kecuali jika perseroan tidak menggunakan hak pemegang saham untuk membeli saham baru, perseroan tidak akan dapat menurunkan rasio kepemilikan sahamnya dengan menerbitkan saham baru, mengenai kewenangan RUPS, Undang-undang Perseroan Terbatas (Syawali \& Imaniyati, 2000).

Menurut Puteri \& Muryanto (2019) Repo merupakan kontrak jual atau beli efek dengan janji beli atau jual kembali pada waktu dan harga yang telah ditetapkan. Sehingga sudah secara jelas diberikan secara jelas pemahaman bahwa transaksi Repo didasarkan pada kontrak (perjanjian). Transaksi repo berlandaskan pada perjanjian yang mewajibkan para pihak untuk melakukan kewajibannya masing-masing dengan baik. Pihak yang tidak dapat melaksanakan kewajibannya harus bertanggung jawab atas perbuatan yang merugikan oleh pihak lain. Seringkali kesepakatan repo saharn ini dilakukan secara berkesinambungan atau di repokan. Seandainya salah satu pihak wanprestasi atau gagal serah maka transaksi repo efeknya akan terjadi secara berantai. Pasal 3 ayat (3) PJOK Tahun 2015 tentang Repurchase Agreement bagi LJK menyebutkan bahwa apabila terjadi peristiwa kegagalan (event of default) dalam transaksi repo, masing-rnasing pihak berkewajiban menyelesaikannya sesuai dengan prosedur penyelesaian peristiwa yang gagal dan hak serta kewajiban yang tercantum dalam perjanjian. Pembelian yang tidak mampu kembali saham, atau pembeli yang biasa disebut gagal serahkan sahamnya kepada pemilik semula (seller) wajib melaksanakan kewajibannya.

Pada dasarnya menurut kelompok hukum yaitu hukum publik dan hukum privat, sengketa pasar modal dibedakan menjadi dua jenis. Asas hukum yang menjadi landasan dari suatu sistem hukum positif sebenamya merupakan abstraksi dari norma/aturan yang lebih luas dan cakupan penerapannnya lebih luas dari ketentuan hukum positif (Atmaja \& Budiartha, 2019). Perbuatan ilegal di pasar modal atau permasalahan dalam hukum publik termasuk dalam bidang hukum pidana dan hukum administrasi, sedangkan permasalahannya daJam hukum privat berkaitan dengan keperdataan. contohnya yang sering terjadi adalah permasalahan daJam perjanjian antara satu pihak dengan pihak lain. Penyelesaian sengketa pasar modal di bidang hukum publik oleh OJK memiliki kewenangan untuk langsung melakukan penyelidikan terhadap pengaduan adanya pelanggaran di bidang hukum pidana dan administrasi. Sanksi administrasi yang diberikan berupa memasukan pihak yang terbukti bersalah ke daftar hitam (blacklist) yang berdampak pihak tersebut tidak dapat melakukan lagi aktivitas di pasar modal Indonesia. Sedangkan dalam hal terjadinya sengketa pasar modal maka solusinya melembutkan tinjauan sebelumnya terhadap syarat-syarat memilih forum penyelesaian perselisihan.

\section{SIMPULAN DAN SARAN}

\section{Simpulan}

Status hukum pemegang saham mayoritas dan pemegang saham mayoritas (PT) yang membeli kembali saham diatur dalam undang-undang Nomor 40 tahun 2007 tentang perseroan terbatas dan Undang-undang Nomor tahun 1995 tentang Pasar Modal. Sebagaimana disebutkan pada pasal 1457 KUHPerdata menjelaskan Jual-beli adalah suatu perjanjian, dengan mana pihak yang satu mengikatkan dirinya untuk menyerahkan suatu kebendaan, dan pihak yang lain untuk membayar harga yang telah dijanjikan. Undang-undang Nomor 40 Tahun 2007 Tentang Perseroan Terbatas mengatur perlindungan hukum bagi pemegang saham minoritas pada perusahaan yang membeli kembali saham di pasar modal, mengatur hak-hak pemegang saham minoritas agar dapat berpartisipasi dalam situasi berikut Undang-undang Nomor 40 tahun 2007 tentang perseroan terbatas merinci perlindungan hukum pemegang saham minoritas pada perusahaan yang membeli kembali saham di pasar modal ,yaitu memberikan hak kepada pemegang saham minoritas untuk ikut serta dalam proses pengadilan perusahaan. Perusahaan dinilai telah melakukan tindakan yang tidak sesuai 
dengan peraturan perundang-undangan perusahaan yang dapat merugikan kepentingan pemegang saham minoritas dan pemegang saham mayoritas. Status hukum pemegang saham rninoritas yang ingin membeli kembali saham perseroan harus memaharni hak dan kewenangan pemegang saham sebagaimana diatur dalam keputusan Undang-undang Nomor 40 tahun 2007 tentang Perseroan Terbatas.

\section{Saran}

Sebagai perjanjian hak membeli kembali saham, maka dalam perjanjian peningkatan hak membeli kembali saham dicantumkan secara tegas tentang tanggung jawab pemegang saham dalam melakukan hak membeli kembali untuk mewujudkan perseroan sesuai ideologi pancasila yang dianut di Indonesia perlu dibuat ketentuan khusus bagi pemegang saham rninoritas dalam undang-undang perseroan terbatas. Apalagi yang berkaitan dengan hak dan kewajiban pemegang saham minoritas. Dalam Rapat Umum Pemegang saham harus memiliki hak suara yang sama terhadap pemegang saham minoritas dengan pemegang saham mayoritas karena berkaitan dengan kemajuan perusahaan serta kepentingan rnasing-masing perusahaan. Untuk rnelaksanakan atau mengoperasikan suatu perusahaan di Indonesia untuk itu perusahaan tersebut diharuskan untuk memperhatikan dan menjalankan Good corporate Governance, maupun memberikan perlindungan hukum terhadap pemegang saham minoritas maupun pemegang saham mayoritas agar korban kepentingan antara pemegang saham minoritas dan pemegang saham mayoritas bisa dikurangi.

\section{DAFTAR PUSTAKA}

Atmaja, I. D. G., \& Budiartha, 1 N. P. (2018). Teori-Teori Hukum. Setara Press. Malang.

Atmaja, I. D. G., \& Budiartha, 1 N. P. (2019). Sistematika Fllsafat Hukum. Setara Press. Malang.

Darmadi, T. (2016). Hukum Pasar Modal. Prenada Media Group. Jakarta.

Dougall, H. E. (2004). Capital Markets and Institutions. Englewood Cliffs. New Jersey.

Mufidah, A. (2013). Buy Back Saham Sebagai Sebuah Alternatif Kebijakan. Jurnal Ekonomi Akutansi Dan Manajemen, 12(1), 25-30.

Puteri, K. A., \& Muryanto, Y. T. (2019). Pengaturan Hukum Transaksi Repurchase Agreement (Repo) di Indonesia. Jurnal Privat Law, 7(2), 211-215.

Sandrawati, E., Siregar, M., \& Isnaini. (2018). Perlindungan Hukum terhadap Investor dalam Perjanjian Jual Beli Saham dengan Hak Membeli Kembali (Repurchase Agreement) yang diperjualbelikan PT. OSO Securities Cabang Medan. ARBITER: Jurnal Ilmiah Magister Hukum, 1(2), 109-116.

Sawidji, W. Cara Sehat Investasi di Pasar Modal. PT Elex Media Computindo. Jakarta.

Syawali, H., \& Imaniyati, N. S. (2000). Hukum Perlindungan Konsumen. Mandar Maju. Bandung.

Tumewu, A. M. (2018). Akibat Hukum Wanprestasi tentang Jual Beli Serta Penyerahan Hak Milik Menjadi Terang dan Tunai. Jurnal Lex Privatum, 6(5), 42-47.

Widjaja, G. (2009). Seri Pengetahuan Pasar Modal Go dan Go Private di Indonesia. Kencana. Jakarta. 